\title{
Realist Magic in the Fiction of William Dean Howells
}

\author{
STEPHANIE C. PALMER
}

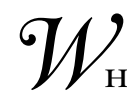

HEN the character Bartley Hubbard in William Dean Howells's A Modern Instance (1882) brags that the ideal newspaper would solicit "an account of suicide, or an elopement, or a murder, or an accident" from "every fellow that could spell, in any part of the country," he voices Howells's own misgivings about the sensational aspect of communication through mass culture. ${ }^{1}$ Rather than fostering cognitive and emotional connections between diverse social groups for the purpose of preventing further suffering, newspaper accounts of personal calamities or largescale industrial accidents in the late nineteenth century tried to thrill readers solely for the purposes of prestige and circulation. Howells was not committed to determining how to prevent suicide, murder, or industrial accidents, but he had a deep interest in determining what-if not sensational tales of fortune and disaster-would inspire people from different economic, political, and religious backgrounds to see each other as respected members of a human community. Howells's key

Nineteenth-Century Literature, Vol. 57, No. 2, pp. 210-236. ISSN: 0891-9356.

(C) 2002 by The Regents of the University of California/Society. All rights reserved.

Send requests for permission to reprint to: Rights and Permissions, University of California Press, Journals Division, 200o Center Street, Suite 303, Berkeley, CA 94704-1223.

1 William Dean Howells, A Modern Instance, ed. George N. Bennett, David J. Nordloh, and David Kleinman, vol. 10 of A Selected Edition of W. D. Howells (Bloomington: Indiana Univ. Press, 1977), pp. 264, 263. 
devices for bringing about this social cohesion are not murders or trainwrecks but chance meetings, injuries during travel, and feelings of accidental entanglement. These devices comprise Howells's particular aesthetic of accident: in his novels such unplanned occurrences serve the purpose of fostering cognitive and emotional connections between social groups. It is important to note that these devices fail to foster long-lasting connections: the novels emphasize that social fragmentation cannot be combated with serendipitous meetings alone. And yet the devices do foster conversations that might serve as the first step toward lasting social cohesion in the future. This particular use of accident was tied up in Howells's generic program of literary realism, and it is significant that accidents appear frequently in his fiction of the 188 os, the decade in which he was developing that program. Although they have overlooked accidents as an ingredient in American literary realism, recent scholars have suggested that the genre was fundamentally about democratic aspirations and failures. Their arguments can shed light on the specific ways that accidents in Howells's novels do and do not foster social cohesion, and an examination of these accidents adds to the study of democracy in realism.

Scholars have debated the success of American literary realism's democratic aspirations, many of them focusing on the fiction and criticism of Howells, the genre's key promoter. Howells formulated realism around the principle of extending literary representation beyond the genteel classes to groups formerly neglected or idealized in literary representation. He was often a generous promoter of provincial, black, Jewish, and socialist authors, and his personal politics became increasingly socialist in the late $188 \mathrm{os}^{2}{ }^{2}$ Yet his novels and criticism include both democratic and anti-democratic impulses. As Amy Kaplan, Elsa Nettels, and Kenneth W. Warren have argued, Howells's

${ }^{2}$ For good analyses of Howells's mentoring, see Sharon M. Harris, Rebecca Harding Davis and American Realism (Philadelphia: Univ. of Pennsylvania Press, 1991), who argues that the Atlantic Monthly published less fiction by women after Howells became literary editor; Joseph R. McElrath, Jr., "W. D. Howells and Race: Charles W. Chesnutt's Disappointment of the Dean," Nineteenth-Century Literature, $5^{1}$ (1997), 474-99; and Jesse S. Crisler, "Howells and Norris: A Backward Glance Taken," Nineteenth-Century Literature, $5^{2}$ (1997), 232-51. 
fictional attention to social environment tends to fix characters within a rigidly stratified world. Kaplan emphasizes that Howells's novels try to pave meeting grounds between his middleclass readership and the upper and lower classes, but that they organize these meeting grounds around a middle-class sense of the familiar; as a result, his novels work to contain the threatening, competing realities of labor-capital conflict and mass culture. ${ }^{3}$ Nettels and Warren argue that dialect, slang, immigrant speech, and the crude manners of characters like the Dryfoos sisters make it appear that people not born into gentility cannot master the skills required to be granted membership in genteel circles. ${ }^{4}$ Howells portrays other characters, such as the country bumpkin Egeria in The Undiscovered Country (1880) or the black janitor in A Hazard of New Fortunes (189o), as romantically different, an identity that prevents them from making their opinions heard in the genteel circles of the "foregrounds" of the novels. ${ }^{5}$

Enriching these readings, Brook Thomas focuses more on realism's democratic promise. In American Literary Realism and the Failed Promise of Contract, Thomas asserts that realism's wide social fabric is formally and thematically shaped around a contractual conception of justice: social problems are solved through human negotiations, not references to a cosmic order, and conceptions of right and wrong change with history. Thomas argues that this nineteenth-century conception of justice remains an ideal worth taking seriously, despite the discrimination pointed to by Warren and Nettels that makes some players more powerful negotiators than others. In an assertion that is important for my argument, Thomas emphasizes the necessity of spoken communication in Howells's fiction: "[Howells] tried to imagine how a more equitable social order could be achieved through immanent exchanges within a heteroge-

\footnotetext{
3 See Amy Kaplan, The Social Construction of American Realism (Chicago: Univ. of Chicago Press, 1988), p. 23.

${ }^{4}$ See Elsa Nettels, Language, Race, and Social Class in Howells's America (Lexington: Univ. Press of Kentucky, 1988); and Kenneth W. Warren, Black and White Strangers: Race and American Literary Realism (Chicago: Univ. of Chicago Press, 1993), pp. 71-89.

5 The metaphor of "foreground" is from Kaplan's analysis of A Hazard of New Fortunes, which she argues is divided between representations of a middle-class foreground and a background of the "unreal" city (see Social Construction, pp. 44-64).
} 
neous society made up of competing interests. Invested in a vision of social harmony, he saw his role not as an imposer of order, but as a translator facilitating communication among various social groups." 6

These critics do not address the means by which effective meeting grounds are formed - the means by which the middleclass containment described by Kaplan gives way to the communication between social groups described by Thomas. The accident-devices of chance meetings, transportation injuries, and accidental entanglement bring about the necessary shifts in Howells's fiction from a stratified space to one that is less stratified, less frenetic, and more appropriate for communication. To the extent that Howells's novels enact a desire for facilitating communication, accidents work as the fulfillment of an authorial wish. ${ }^{7}$ Missed train connections and chance meetings force the middle-class characters of the novels" "foregrounds" into a realization of train schedules, labor politics, tramps, slum dwellers, and morally compromised millionaires. More abstractly, these incidents entangle the lives and interests of disparate characters - they are a sign for readers of the involvement of bourgeois individuals in industrialism and a socially divided nation. Yet in Howells's novels this authorial wish for communication is imperfectly fulfilled or disastrously unfulfilled. While some of his contemporaries nurtured accidental social connections in their fiction, Howells reminds readers of the implausible nature of these connections. In doing so he emphasizes the deep-seated effects of social inequality upon human interaction.

By calling this dynamic "accident" I am codifying a characteristic of Howells's writing that scholars have perceived for

${ }^{6}$ Brook Thomas, American Literary Realism and the Failed Promise of Contract (Berkeley and Los Angeles: Univ. of California Press, 1997), p. 285.

7 Freud's discussion in The Psychopathology of Everyday Life (1901) of "bungled actions" that reveal unconscious wishes includes missed train connections and carriage accidents, events similar to those in the fiction of Howells and other late-nineteenthcentury writers (see Sigmund Freud, The Psychopathology of Everday Life, in The Standard Edition of the Complete Psychological Works of Sigmund Freud, ed. and trans. James Strachey, et al., 24 vols. [London: Hogarth Press and the Institute of Psycho-Analysis, 1953-74], VI, 162-90). This suggests that they were familiar motifs in nineteenth-century bourgeois culture. 
years without naming satisfactorily. For example, William Alexander identifies Howells with an ability to represent how middle-class people live richly detailed lives without acknowledging the people, institutions, and events that lie outside their horizons of consciousness. ${ }^{8}$ Tony Tanner has remarked that Howells's novels are filled with chance meetings that attempt to break down this atomism. ${ }^{9}$ And Amy Kaplan explains this double pull of Howells's work as a response to a society made more connected yet more distended by the media, corporations, and complex institutions. ${ }^{10}$ Howells's trope for this type of modern relation, I contend, is accidental entanglement.

Accident serves as a kind of magic in Howells's fiction. His criticism on realism defends literature against the magical elements - such as dei ex machina, ghosts, or shipwrecks - of popular fiction and the high literature of previous periods. ${ }^{11}$ Yet faulty train connections and express trains that run over innocent pedestrians would not have registered with Howells's 1880 s readers as novelistic contraptions alone, but as signs of the immanent present, as technologies that could wreak havoc with the natural world of chance and make the economic risks that men take all the more damaging. And Howells's accidents do not signal the residual moralism of which critics have accused

${ }^{8}$ See William Dean Howells: The Realist as Humanist (New York: Burt Franklin and Co., 1981$)$.

${ }^{9}$ See Tanner, "Introduction" (1965), in William Dean Howells, A Hazard of New Fortunes, ed. John Dugdale (New York: Oxford Univ. Press, 1990), p. xvii.

10 See Social Construction, p. 43.

11 Howells's influential essays on realism in Criticism and Fiction (1891), which he published while writing Annie Kilburn (1889) and A Hazard of New Fortunes, contain lists of inappropriate devices such as heroes, goblins, hair's-breadth escapes, murder, debauchery, arson, ghosts, and shipwrecks (see W. D. Howells, Criticism and Fiction, in Selected Literary Criticism, Volume II: I 886-I897, ed. Christoph K. Lohmann and Donald Pizer, et al., vol. 21 of $A$ Selected Edition [Bloomington and Indianapolis: Indiana Univ. Press, 1993], pp. 328,335 [subsequent references are to this edition and are included in the text]). All of these devices obviate the necessity for authors to acknowledge the importance of social conditions in shaping the motivations and destinies of characters, and they suggest that cosmic forces may bring about changes to literary narrative or social organization. One of the classic defining elements of realism is an adherence to psychological motivation and sociological cause. In addition to Criticism and Fiction, see Theodore Dreiser, "True Art Speaks Plainly" (19o3), rpt. in Documents of Modern Literary Realism, ed. George J. Becker (Princeton: Princeton Univ. Press, 1963), p. $15^{6}$; and George Bernard Shaw, "Ideals and Idealists" (1891), rpt. in Documents, pp. 123-28. 
him. ${ }^{12}$ They do not produce morally pleasing endings or radically changed societies; instead, they remind readers of the need for, and the difficulty of, maintaining cognitive and emotional connections in a heterogeneous society. They are just as modern as other modern understandings of "accident" as a concept and event: accident as a media commodity, accident as proof of the necessity of the insurance industry, and accident as a signal for an unconscious wish. In The Undiscovered Country, Annie Kilburn, and A Hazard of New Fortunes Howells alludes to all of these associations - which suggests that he was actively choosing rather than passively accepting a kind of modernity. ${ }^{13}$ I begin my reading by tracing the way that chance meetings and other accidents function in The Undiscovered Country, a novel in which urban travelers and tourists "explore" the country. In this novel Howells shows how "realist" accident evolves from "pastoral" accident. He redacts literary pastoral with situations in which rural people are uninterested in providing spiritual refreshment and conviviality to their urban visitors. Yet rather than replacing the pastoral with images of rural and urban irreconcilability, Howells posits a modern hope that connections made by accident might lead to permanent understanding and coherence. A similar realist device of accident informs the later novels Annie Kilburn and A Hazard of New

12 On the tendency to criticize the ending of The Rise of Silas Lapham (1885), see Donald E. Pease, "Introduction," in New Essays on "The Rise of Silas Lapham," ed. Pease (New York: Cambridge Univ. Press, 1991), pp. 1-28.

${ }^{13}$ In fact, Howells uses the term "accident" in ways that appear to parody its contemporary currency: he uses it in The Undiscovered Country to refer to Ford's injuring of Egeria's hand and to Boynton's missing the train at Ayer Junction (see W. D. Howells, The Undiscovered Country [Boston: Houghton Mifflin, 188o], pp. 42, 223). He also uses the term in A Hazard of New Fortunes to refer to Miss Woodburn's "incredible accident of her preference of [Fulkerson] over other men" and to Beaton's aimless hope in looking down the barrel of his revolver that it would "go off by accident and kill him" (see W. D. Howells, A Hazard of New Fortunes, ed. David J. Nordloh, et al., vol. 16 of A Selected Edition [Bloomington: Indiana Univ. Press, 1976], pp. 378, 491). Characters in each of the three novels I examine resort to heated discussions over conflicting interpretations of specific accidents (such as Edward Ford's being stuck in Vardley or Basil March being caught in the horse-car strike). Rather than encouraging readers to choose one view over another (as some critics have suggested he does), Howells makes readers imagine accepting each of the characters' interpretations in turn. (Subsequent references to The Undiscovered Country and A Hazard of New Fortunes are to these editions and are included in the text.) 
Fortunes. In contrast to The Undiscovered Country, these two later novels represent the social coherence made possible through accident as only an imperfect solution to social fragmentation and inequality. In Annie Kilburn Howells's faith in the social fiction of accident shifts into a critique of the subject that relies most frequently on the accidental to generate social changethat is, the well-intentioned but cloudy-headed middle- or upper-class subject. Yet the novels themselves enact accidents in an attempt to make readers connect, and in A Hazard of New Fortunes Howells refines and partially refutes some of Annie Kilburn's criticism of the well-intentioned middle- or upper-class subject.

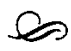

Critics have often identified The Undiscovered Country as a transitional novel between two periods of Howells's production: the 1860 and 1870 , which were dominated by his travel books and humorous courtship novels, and the 1880 s, in which his major works were realist novels of the city. ${ }^{14}$ Nearly all Howells critics consider the novel to be minor, and many judge it an aesthetic failure. ${ }^{15}$ Their judgments may be related to the novel's discontinuous generic code: it combines the genres of pastoral, realism, and Hawthornesque romance of the psyche in a seemingly aimless way. While the first fourteen chapters ironically expose the fraud of spiritualism and the impossibility of harmony between different social groups, the final ten chapters soberly explore the psychology of

14 John W. Crowley posits these categories in "Howells in the Eighties: A Review of Criticism, Part I," ESQ, 32 (1986), 253-77.

15 In a detailed examination of Howells's courtship novels, Bert Bender singles out The Undiscovered Country as singularly poor, consisting of "a nearly endless series of struggles (in what is certainly one of Howells's most agonized and heavy-handed performances)" (The Descent of Love: Darwin and the Theory of Sexual Selection in American Fiction, I87I-I926 [Philadelphia: Univ. of Pennsylvania Press, 1996], p. 73). Richard H. Brodhead dropped the novel from his examination of Hawthorne's influence upon Howells; for a comparison of his treatments, see Brodhead, "Hawthorne among the Realists: The Case of Howells," in American Realism: New Essays, ed. Eric J. Sundquist (Baltimore: Johns Hopkins Univ. Press, 1982), pp. 25-41; and Brodhead, "Howells: Literary History and the Realist Vocation," in his The School of Hawthorne (New York: Oxford Univ. Press, 1986), pp. 81-103. 
interpersonal influence and love. This discontinuity makes the novel difficult to read and interpret.

The greatest advocate of The Undiscovered Country has been Kermit Vanderbilt, who makes a strong case for its major status in the Howells canon on the basis of its being a post-Civil War reenvisioning of the pastoral. ${ }^{16}$ In the novel two sets of weary urban characters (Boynton and Egeria, and Ford and Phillips) venture into the countryside, where the powers of "nature" restore their physical, emotional, and spiritual health. The novel is a revision of the pastoral, argues Vanderbilt, because it emphasizes the social stratification and social changes (the breakdown of sexual and familial morality) that affected both country and city in the 1860 ond 1870 . Rather than peace and timelessness, the characters find disreputable and incongruous types, including prostitutes, tramps, migrant woodcutters, poor Southern whites and blacks, and noisy lower-class tourists.

Howells's revision of the pastoral in The Undiscovered Country is more intricate than Vanderbilt's reading implies, for the representation of country space in the novel indexes a struggle between competing generic ideologies of human cohesion. In the novel's opening the urban characters generally assume that country people will be charming, generous, and unthreateningly different, as country characters would be in a pastoral. But instead the country characters are complex and subject to the same spiritual quests and economic concerns as the urban characters themselves. Howells replaces the urban characters' assumptions of boundless country hospitality with an idea of accidental entanglement that characterizes his later novels about the city. In addition, dissenting characters voice skepticism about whether such accidental entanglement is meaningful or helpful. There are three aesthetics of accident in The Undiscovered Country: pastoral accident, Howellsian realist accident, and part-Puritan, part-utilitarian critiques of realist fictionalizing around accident.

${ }^{16}$ See The Achievement of William Dean Howells: A Reinterpretation (Princeton: Princeton Univ. Press, 1968), pp. 11-48. Twenty-first-century readers may wonder why Vanderbilt did not characterize the novel as regional, since his description of its close attention to actual social types and their meetings resembles current critical definitions of nineteenth-century regional writing. In the 1960 s that label would have been considered too minor to support his argument for the novel's importance. 
The novel's plot is important for my argument. The novel begins in Boston, where Mr. Boynton, a man from Maine, experiments with using his acquiescent but hesitant daughter, Egeria, as a spiritualist medium. They consort with a fashionable but not quite respectable group of men and women, the boarding house crowd, in which they meet Edward Ford, an indecisive young man unable to find satisfaction in either chemical experiments or magazine writing. In the novel's first chance meeting, Ford and his friend Phillips visit a seance arranged by Boynton's landlady, in which Boynton demonstrates his powers over Egeria. Out of scientific skepticism rather than maliciousness, Ford disrupts the seance with actions that Boynton attributes to the spirits: he squeezes Egeria's hand so hard that he injures her, and he lights a gas lamp. Ford's squeezing of Egeria's hand constitutes the novel's first major accident: it is a sudden, unwelcome event that serves to link the fates of Ford and Egeria. Ford then incenses Boynton by revealing that the entire seance was a fraud, and he refuses Boynton's request to restore Boynton's honor through another seance. Feeling defeated, Boynton attempts to return to Maine, but his journey is interrupted in the novel's second major accident: his eagerness to listen in on the conversation of a group of Shakers at Ayer Junction causes him and his daughter to miss their train. They mistakenly board the southbound instead of the northbound connection and find themselves without their luggage or money at the next stop, near Egerton, Massachusetts. After many unsuccessful attempts at finding shelter and assistance, during which Egeria falls dangerously ill with fever, they house with a Shaker community in the town of Vardley. Feeling himself to be at home in a community of spiritualists, Boynton endeavors to interest the Shakers in his own spiritualist experiments. But they resist his entreaties, preferring his acquiescent and humble daughter, who gains independence and confidence in the course of picking berries and pretty leaves in the neighboring fields.

At the very moment that the latent hostility becomes explicit between Boynton and the Shaker Elihu, Ford and Phillips arrive at the Shaker community, stopping for the night during an antique-buying expedition. In the novel's third major accident, Ford stumbles across Boynton sleeping outside. Remem- 
bering Ford as the man who dishonored him, Boynton attacks Ford, hits his own head in the struggle, and suffers from apoplectic seizures and contusions that send him into a decline ending in death. Bidding good-bye to Phillips, Ford remains in Vardley to assist the Boyntons. In the course of conversations in the meadows and at Boynton's bedside, Ford and Egeria fall in love, and Ford and Boynton resolve their difference of opinion about science and spirituality. After Boynton's death, Ford and Egeria move to the Boston suburbs, where Ford's patent for a common household chemical earns them a middle-class living.

The novel's representational codes redact the pastoral. By providing precise detail about people and places, the novel complicates the pastoral plot in which city people go to nature in order to be rejuvenated. These codes resemble those of Howells's urban novels of the 1880s, codes that Amy Kaplan identifies as realist. Kaplan explains how realism contrasts a middle-class domestic "foreground" to the "unreal" city composed of the working classes and capitalist elite. She identifies the middle-class couple in A Hazard of New Fortunes, Basil and Isabel March, as vehicles for representing a middle-class response to the new, unsettling anonymity of city life. For Kaplan the Marches are mobile, realist characters "preoccupied with the problem of inhabiting and representing rented space" (Social Construction, p. 12).

Yet the characters in The Undiscovered Country cannot be identified simply as "urban" or "rural." The Boyntons are not at home anywhere: in Boston they develop neither a social network nor knowledge of city life, and Boynton's single-minded dominance over his daughter has alienated them from their remaining relative in Maine. Similarly, the Shakers come from diverse backgrounds: Brother Humphrey speaks in heavy country dialect, yet Sister Francis has a fashionable sister in Boston, and while some of the Shakers find Boynton's spiritualism religiously inspiring, others consider it a corrupt modern practice and still others see it as a welcome source of entertainment.

Rather than portraying rural people as quaint and generous, the novel reminds readers of the absence of communal feeling between socially separated groups in the modern Massachusetts countryside. Noting Egeria's shabby dress, the con- 
ductor of the train does not believe their story about the northbound money and luggage, and orders them off at the Egerton stop. Without money, Boynton and Egeria wander through a vacation community, forests, hobo camps, and vacated farmland. When seeking assistance or shelter they are mistaken for tramps, drunks, and a reform school dropout and her accomplice. The Shakers eventually house them, not out of spontaneous feeling between equals, but because they have a policy of accommodating tramps as well as paying guests.

The novel represents the countryside as a space of class conflict and modern unknowability. Much as Howells used the Marches' walks through the poor neighborhoods of New York City, he uses the Boyntons' buggy rides through the country to capture competing versions of modern reality. While recovering from her fever, Egeria is rejuvenated by her wanderings through the neighborhood in the traditional pastoral fashion she gathers flora and picks berries, and with each walk she gains energy, happiness, and confidence. Yet her idea of nature coexists with the nature worked by poor fieldhands and inhabitants of rickety shacks. For example, migrant Canadian woodcutters, hired by the Shakers, salvage firewood from the same cleared grounds where the Shaker women and Egeria pick berries. Like the city, and like death (to which the novel's title explicitly alludes), the Massachusetts country is rendered into an "undiscovered country."

One of the startling lessons that nineteenth-century readers learned while looking over the urban characters' shoulders is that the (at least somewhat) hospitable Shakers did not share the Boyntons' expectations of a common ground. ${ }^{17}$ Knowing that the Shakers practice spiritualism, Boynton expects them to

17 On nineteenth-century representations of Shaker villages, see Robert Michael Pugh, "A Thorn in the Text: Shakerism and the Marriage Narrative," Ph.D. diss., Univ. of New Hampshire, 1994, pp. 23-61. Pugh argues that the real-life Shaker community paid a great deal of attention to the fiction of Howells and other outside writers who portrayed Shakers in fiction; he finds that Shakers enjoyed Howells's scrupulousness but objected to his dismissal of their sexual and marital choice. Pugh himself finds Howells's Shakers to be quaint, and he argues that Howells sublimates the viability of celibacy as an alternative to marriage. I disagree. Howells did portray Shakers as an outsider might, with inaccuracies and a lack of sympathy or understanding, but his Shakers are not simplistically quaint, and he deals rather explicitly with what he thinks it means to choose against marriage. 
be thrilled at the news of his success in calling the spirits, and Phillips arrives ready to bargain for their furniture and ornaments. But the Shakers thwart these expectations, and friction between the guests and the host comes to the fore. It is significant that this friction is expressed through the Shaker Elihu's reinterpretation of the accident of Boynton boarding the wrong train. Boynton interprets this occurrence as a divine sign-he speaks joyfully of the "chance" meeting at the train depot that led him into the Shakers' fold (p. 181). But the Shakers do not trust him, and, sensing this, Boynton appeals to his own ideal of hospitality: "You led me to believe that among you I should find the sympathy and support which are essential to success" (p. 223). Brother Elihu replies: "We led you to believe nothing. . . . An accident threw you among us, after we had fully and fairly warned you that we should not receive you or any one without deliberation. We welcomed you kindly, and you have had our best" (p. 223). Elihu thus expresses the possibility that chance meetings and accidental social connections are not to be trusted as a basis for communal feeling.

Elihu brings to the fore the novel's question about the social construction of the meaning of accident-about whether an accident should be made to signify something beyond itself. According to Elihu, Boynton's accident in boarding the wrong train is meaningless, and Elihu's words (while softened in another scene) crystallize an important counterargument to Howells's dominant argument. Howells is famous for proposing that reading good literature, thinking morally, and finding meaning in everyday life are key, related ways of combating the modern fragmentation caused by mass culture and class conflict. The essays that he wrote for Harper's Monthly between 1886 and 1892 (and included in revised form in Criticism and Fiction) suggest that realism can be a moral force if created by a careful author. Yet Howells also expressed indecision in this regard, suggesting in some essays that the author's addition of meaning is important, while suggesting in others that reality, morality, and good art are inseparable regardless of the author's conscious intentions. ${ }^{18}$ Thus Elihu's outburst connects to

${ }_{18}$ For example, in arguing that attributing meaning to common facts necessarily involves a moral outlook, Howells distinguishes between a lesser realism that "heaps up 
a central question that Howells was considering at this point in his career, the question of whether social fictions (and hence realist literature) can be meaningful and hence powerful. Elihu's reply is a counterpoint to Howells's critical speculations about the viability of attaching meaning to common events: Elihu suggests that Boynton's accidents do not constitute moral phenomena - that is, they are not a significant sign of the rightness of the fit between Boynton and the Shakers. To Howells's question of what cohesive fictions might be powerful enough to replace the outdated institutions of hospitality, Elihu replies: nothing. In that sense, he throws into relief the fictions of modern urbanity.

The narrative puts forth two other rationalist perspectives on the place of accident in modern life. One is voiced by the Boyntons' friend Hatch, who accompanies them to the Ayer railroad depot. When Boynton exclaims that he overheard the Shakers discussing "the life hereafter . . . and the angelic life on earth," Hatch replies: "Well, I don't know about the last, but the first is a good subject for a railroad depot. Makes you think whether you've bought your insurance ticket" (pp. 118-19). The conjunction of death and the railroad make Hatch think of damage to life and limb-accident, from the perspective that the insurance industry developed in the early nineteenth century. Hatch's wry remark hints at a worldview in which chance is bothersome, even destructive, and to be avoided, and in which the best way to avoid it is by purchasing a market product. In this worldview there is no reaching beyond the realm of the social and the calculable. ${ }^{19}$ Thus in The Undiscovered Country we see insurance technology in tension with another modern

facts merely, and maps life instead of picturing it," and a better realism in which the author "is careful of every fact, and feels himself bound to express or to indicate its meaning at the risk of over-moralizing" (Criticism and Fiction, p. 302). In contrast, his claims discounting authorial intentions occur primarily in hortatory passages: "Morality penetrates all things, it is the soul of all things" (Criticism and Fiction, p. 322 ).

19 For more on the insurance worldview, see François Ewald, "Insurance and Risk," in The Foucault Effect: Studies in Governmentality, ed. Graham Burchell, Colin Gordon, and Peter Miller (Chicago: Univ. of Chicago Press, 1991), pp. 197-210. Ewald argues that the technologies of the early-nineteenth-century insurance industry began to rewrite the concepts of randomness and possibility into the concept of calculable, collective risk. 
worldview in which accident is to be embraced as a secular, social path to human connectedness.

The other rationalist perspective on accident is expressed by Ford in Boston, at the beginning of the narrative, when he objects to social niceties, white lies, and fictions. Ford criticizes Phillips and Hatch for dabbling in activities in which they have only provisional faith: "He [Hatch] dabbles in ghosts as you [Phillips] dabble in bricabrac. He believes as much in ghosts as you believe in your Bonifazios. They may be genuine; in the mean time, you like to talk as if they were. Upon the whole, I believe I prefer blind superstition" (p. 86). Ford abhors Phillips's and Hatch's way of enjoying fashionable and modern activities that they themselves acknowledge to have merely socially constructed value. Similarly, Ford abhors using an accident as an excuse for an individual's irrational decisions: when Boynton attributes his tardiness in confronting Ford about the seance to needing to save a child who had been run over in the street, Ford considers the occurrence as "rather too opportune" (p. 92)..$^{20}$

But in the narrative's second half, once Ford feels "accidentally" enmeshed with Boynton and Egeria, he very much embraces modern social fictions. He begins to enjoy walks in the forest, and he accepts a moral interpretation of his fight with Boynton, as he explains to Phillips: "I can't say that I am responsible for the misfortunes of this man, but somehow I am entangled with him, and I can't break away without playing the brute" (p. 269). ${ }^{21}$ To Elihu, who accuses him of courting Egeria in a way that might tempt the Shakers (committed to celibacy)

20 The sense that modern activities redound in fictitious value and meaning resonates widely both with T. J. Jackson Lears's idea of the late-nineteenth-century middle-class sense of weightlessness (see Lears, No Place of Grace: Antimodernism and the Transformation of American Culture, I $880-1920$ [New York: Pantheon, 1981]), and with Walter Benn Michaels's characterization of the period's writing, photography, and courtship as embracing slippery signification and the aleatory (see Michaels, The Gold Standard and the Logic of Naturalism: American Literature at the Turn of the Century [Berkeley and Los Angeles: Univ. of California Press, 1987]).

${ }^{21}$ In the case of Ford, the sense of accidental entanglement overrides a brutishness that the uncultured Ford finds "instinctive." Ford's development in the course of the narrative draws on the idea that lower-class people (especially lower-class men) are brutish, and middle-class people practice self-control. His development is part and parcel of the distinction between realism, in which (roughly) accidents may be felici- 
to fall in love themselves, Ford equivocates: "Do you think these are the circumstances for love-making? I am here very much against my will, because I can't decently abandon a friendless man" (p. 350). It is significant that Howells has Ford understand and narrate his change in thinking with the language of being abducted or enchanted: the narrative posits a premodern way of enchanting characters into embracing the risks and pleasures of the modern world. Thus, Howells does not choose the rationalist and utilitarian interpretations of accident to resolve the novel; rather, the conclusion embraces the possibility that accidental meetings and conversations can be meaningful.

Through a realist social fiction of accident, Howells in The Undiscovered Country posits hope for modern social connections among people who do not share a history, community, family, or political affiliation. He most clearly mobilizes this concept of modern social connection in Ford and Egeria's courtship, but he also deploys it in order to portray provisional relations between communities and places. Ford and Egeria become friendly with the Shakers not because they are essentially like them, but because they are in circumstances that provide them with a common ground for friendship. Howells responds to the modern tension between community and mobility in both country and city by positing the viability of temporary emotional coalitions. These emotional bonds make possible the peaceful yet probing conversations between Egeria and Ford, Ford and Boynton, and Boynton, Ford, and the Shakers. Yet these emotional bonds remain selective: the Shakers are a relatively knowable and similar country group for the urbanites to be thrown in with, and Ford is a relatively sympathetic Howellsian, rising "brute" character. In the late 188 os, however, the same realist deployment of accident for the purpose of fostering social cohesion is not as successful.

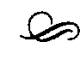

In both Annie Kilburn and A Hazard of New Fortunes the figures of the chance meeting, the sense of acci-

tous and determined by characters' actions, and naturalism, in which human life is an accident and characters' actions are determined by their instincts. 
dental entanglement, and sudden death during travel all serve purposes similar to those of the accidents in The Undiscovered Country: they foster meetings between socially divided people and devise ways for the novelistic narrative to move beyond its middle-class foreground. The sense of accidental entanglement vivifies a means by which middle-class characters might deal with their expanded horizon of social impact by expanding their horizon of consciousness. All three figures of accident signal the involved yet partially ignorant role of the individual within complex organizations - voluntary associations, the literary marketplace, and city space. With accidents Howells constructs new forms of "incidental," or nonfoundational, responsibility that are appropriate for a modern world in which an individual's actions and thoughts affect people outside of family or community. Accidents in these two novels reveal the characters' complicity with the economic or socially oppressed, with the local gentry with whom Annie Kilburn associates, and with the capitalist who supports the artistic production of Basil March, Alma Leighton, and Angus Beaton.

In examining the expanded horizons of social consciousness brought about by modern transportation and communication, I draw on Thomas L. Haskell's theory about the connection between the growth of the humanitarian sensibility in the eighteenth century and the growth of a market economy. Haskell argues that the humanitarian sensibility required a "broaden [ing of] the sphere within which a person may potentially feel himself to be the cause of an evil." ${ }^{22}$ He speculates that this broadening came about as a result of a market economy that habituated people to making transactions across stretches of time and space - thus, a national literary market might have habituated actual nineteenth-century readers to feel social obligations across distance. Howells's two later novels thematize the possibilities and problems of the expanded but attenuated consciousnesses of readers. On this point, Wai-Chee Dimock argues that in The Rise of Silas Lapham and The Minister's

\footnotetext{
22 Thomas L. Haskell, "Capitalism and the Origins of the Humanitarian Sensibility, Part 1," in The Antislavery Debate: Capitalism and Abolitionism as a Problem in Historical Interpretation, ed. Thomas Bender (Berkeley and Los Angeles: Univ. of California Press, $1992)$, p. 134 .
} 
Charge (1887) Howells proposes an "economy of pain" in which characters who do not limit their humanitarian actions court disaster. ${ }^{23}$ But how do they decide which obligations to act upon? Howells's use of accidents to urge his characters to a decision suggests that there is a certain amount of arbitrariness and circumstance built into the system of modern humanitarianism.

In Annie Kilburn and A Hazard of New Fortunes all devices of accident are not of equal value: Howells thematizes a contrast between "accidental entanglement" and "activism-theory." He identifies a sense of accidental entanglement primarily with middle- or upper-class characters who feel a desire to contribute to the cause of social justice, and he represents it as feminine because it is unthinking and often ineffective. I label such characters the "well-meaning bourgeois." Howells identifies activism and theory with the Reverend Peck, the socialist Berthold Lindau, the religious would-be minister Conrad Dryfoos, and the committed altruist Margaret Vance - the "activisttheorists." ${ }^{24}$ These characters resist bourgeois ideas of comfort and American ideas of innocence by reading socialist thought, participating in worker cooperatives, and actively attempting to make the upper classes and small-business owners recognize their role in increasing social inequality.

While the well-meaning bourgeois in these two later novels experience a sense of accidental entanglement, activist-theorists experience fatal injuries during travel. In Annie Kilburn Mr. Peck is hit by an express train while crossing the depot on his way out of Hatboro to set up a cooperative house and school for millhands in another town. And in A Hazard of New Fortunes policemen shoot Conrad and club Lindau while the two men, wandering through the city, attempt to intervene in a demonstration by streetcar strikers. The message transmitted by the different effects of accidental entanglement and accidental death is

${ }^{23}$ See Wai-Chee Dimock, "The Economy of Pain: Capitalism, Humanitarianism, and the Realistic Novel," in New Essays on "The Rise of Silas Lapham," pp. 67-9o.

${ }^{24}$ No single character represents a pure embodiment of either activism-theory or accidental entanglement. Many of Howells's key characters (the Boyntons and the Marches, for instance) are not economically secure enough to maintain the perfect observational distance required for Annie's continual quandaries over her horizons of causality. Further, characters like Conrad Dryfoos feel both willed and unwilled longings to do good. Like any identity, these identities are mixed. 
that truly activist characters are too good, and in some ways too extreme, to exist in the novels' worlds of middle-class plausibility - the deaths serve as a wake-up call for readers. Still, the historical Howells cannot be simplistically identified with either accidental entanglement or activism-theory. ${ }^{25}$ The novels clearly endorse the theoretical viability of the activisttheorists, yet they do not portray the accidentally entangled characters as simple foils. Instead, these characters demonstrate how difficult it is to deal with expanded horizons of causalityor, in other words, how difficult it is to perform actions that bring about more than personal fulfillment.

In Annie Kilburn Howells compares three methods for building common ground among the established gentry, rising elite, summer people, immigrant workers, and farm laborers of a New England factory town. The least viable method is that of a group of Hatboro residents, comprised of the local elite and the rising entrepreneurs, who attempt to establish a social union for the town's factory workers. The organizers' union appears unlikely to meet the long-term needs and short-term desires of the factory workers, and it smacks of condescension and social control. The meetings illustrate that these reformers are primarily motivated by a desire to assure social influence, and in portraying them Howells lampoons social reform.

The second method is that of the radical Reverend Mr. Peck, who openly criticizes the philosophical assumptions of the social union. He explains that working-class people have fundamentally different needs that are not best understood with middle-class intuition. The social union organizers see Peck as frighteningly emotionless and abstract, and they see his apparent neglect of his child (he is a single parent) as proof of his heartlessness.

The third method is that of Annie Kilburn, a well-meaning bourgeois, who mediates between the unthinking reformers

25 It is clear from the letters that Howells wrote during and after the composition of Annie Kilburn that he believed that the novel's message was that Peck's revolution, not Annie's reform, was the solution to social inequality. See Howells, letter to Hamlin Garland, 15 January 1888, in Howells, Selected Letters, Volume 3: I882-I89I, ed. Robert C. Leitz III and Christoph K. Lohmann, et al., vol. 19 of $A$ Selected Edition (Boston: Twayne, 1980 ), pp. $214^{-1} 5$. Yet I agree with Hamlin Garland that the novel itself ends with great hope for Annie's eventual success at helping the factory workers on a local level. 
and the theoretical Peck. A member of the Hatboro gentry who returns from Washington, D.C., and Europe to the home of her youth because she is tired of the disoccupation of expatriate communities, Annie reestablishes herself in Hatboro with inarticulate longings to "be of some use" and "try to do some good." ${ }^{26}$ She exemplifies a modern, privileged longing for the perceived permanency and mutually supportive nature of life in an American small town.

Howells constructs Peck as thinking and Annie as feeling. For example, when Annie sends two sickly children to the seashore in hopes of a cure, she is acting on her own intuition, without consulting a physician. Similarly, she is unable to explain why she dislikes the idea of the social union until Peck offers his reasons, and then she feels that "Mr. Peck had given her a point of view, and though she believed she did not agree with him, she could not escape from it" (p. 742 ).

Annie's reactions here reveal her method of reform to be an unwilled, felt impulse. In this novel Howells suggests that this method is both harmful and helpful: it enables Annie to question the status quo and examine her own actions, yet her actions also contribute to a child's death, as one of the sickly children dies during the journey to the seashore. Thus Annie's sense of entanglement is an example of the modern individual's ability to effect good or evil: an individual may try to do good across time and distance, but because of natural and human-made chance he or she may fail.

At the same time, however, Annie's impulsiveness is inseparable from the aspects of her character that Howells labels as feminine and neurasthenic. In the first half of the novel Howells describes Annie's indecisiveness with lines like this one: "She never could tell by what steps she reached her agreement with the minister's philosophy; perhaps, as a woman, it was not possible she should" (p. 864). ${ }^{27}$ In his other novels as well,

${ }^{26}$ William Dean Howells, Annie Kilburn, in Novels, I886-I888, ed. Don L. Cook (New York: Literary Classics of the United States, 1989), p. 645. Subsequent references are to this edition and are cited in the text.

27 On Howells's generation's differing interpretation of women's and men's neurasthenia, see Tom Lutz, American Nervousness, 1903: An Anecdotal History (Ithaca: Cornell Univ. Press, 1991 ), pp. 4-19; but see also Gail Bederman, Manliness and Civilization: A Cultural History of Gender and Race in the United States, I880-I9I7 (Chicago: Univ. of 
Howells represents women as cloudy-headed, given to accidental connections, and incapable of the individualistic strength that leads to drastic solutions or heroism and, hence, an early death. In A Hazard of New Fortunes the activist-theorist Margaret Vance does not die along with Conrad, whom she urges into the strike's fray, but rather is pushed to the margins of the novel's conclusion, in which she appears as a nun. ${ }^{28}$ As with Egeria in The Undiscovered Country, Vance in Hazard exemplifies feminine suffering and enduring (as opposed to masculine suffering, acting, and dying young).$^{29}$ And yet Howells proposes no alternative for these "feminine" approaches to bringing about social equality and harmony; he may gently scorn feminine forces in his novels, but they are always useful and necessary to the narratives. For example, over time Annie becomes more vocal and logical in her analysis of social stratification in Hatboro. At the novel's conclusion it is evident that her indecision, coupled with her determination to carry on Peck's legacy, might help the town's factory workers and poor. Rather than being the leader of a factory worker cooperative (as Peck had tried to be), Annie works for a cooperative run by the workers themselves. The narrative becomes transcendental in its positive description of her accidental method:

she remained at her door looking up at the summer blue sky that held a few soft white clouds, such as might have overhung the same place at the same hour thousands of years before, and such as would lazily drift over it in a thousand years to come... . A perception of the unity of all things under the sun flashed and faded upon her, as such glimpses do. Of her high intentions, nothing had resulted. ... Nothing of what was established and regulated had desired her intervention; a few accidents and irregularities had

Chicago Press, 1995), pp. 121-69. On Howells's personal resistance to women who seek to work and think outside the home, see John W. Crowley, "Howells: The EverWomanly," and "Winifred Howells and the Economy of Pain," both in his The Mask of Fiction: Essays on W. D. Howells (Amherst: Univ. of Massachusetts Press, 1989), pp. 35$55,83-114$. It is significant that Annie takes action to do good only after her father dies, which leaves her without a male obstacle to action.

${ }^{28}$ For this point about Vance I am indebted to Janice Koistinen-Harris.

${ }^{29}$ On the nineteenth- and twentieth-century association between male heroism and sudden "accidental" or "unnatural" death, see Susan Bennett Smith, "Virginia Woolf and Death: A Feminist Cultural History, 1880-1940," Ph.D. diss. Stanford Univ., 1993. 
alone accepted it. ... She was aware of the cessation of a struggle that has never since renewed itself with the old intensity; her wishes, her propensities, ceased in that degree to represent evil in conflict with the portion of good in her; they seemed so mixed and interwoven with the good that they could no longer be antagonised; for the moment they seemed in their way even wiser and better, and ever after to be the nature out of which good as well as evil might come. (pp. $85^{8-59}$; emphasis added)

The passage appeals not to the civil and social, but to a Romantic permanence, creativity, and release of self-will inspired by nature. ${ }^{30}$ The novel as a whole raises problems with this viewpoint, but the passage nevertheless offers hope that Annie's sense of accidental entanglement is a meaningful and worthwhile method for helping the cause of justice.

In contrast, Howells portrays Peck's activist-theorist method of effecting justice as not viable in the realist world. It leads to his collision with the express train, which prevents a radical conclusion to the novel by keeping Peck from setting up a cooperative and giving his radical message to the congregation. Just as the Boyntons' missed train eventually leads to social unity, so too Peck's accident fosters an opportunity for unity among Hatboro residents. The Savors, a working-class family of reformers, take Peck's severely injured body into their home, and when a crowd, which includes the gentry, enters to visit him, the Savors offer the "vulgar kindliness" of coffee (p. 85o). But this upwelling of feeling is short-lived, leaving Hatboro's social divisions just as strong at the end of the novel as they were at the beginning. The death by express train is a familiar metaphor for the relentless, destructive forces of modernity that Howells seeks to ameliorate through human connections, and it is significant that in his aesthetic these forces are most dangerous to a radical character. ${ }^{31}$

${ }^{30}$ In Black and White Strangers Warren identifies American literary realism with the civil and the social, and hence with a rigid adherence to what a racist, elitist public would consider plausible. I stress that with accident Howells seeks to mediate between the realist realm and the nonrealist (sentimental or romantic) realm of justice beyond plausibility. Thus, the device signals a way in which Howells attempts to produce justice within a realist aesthetic.

31 Leo Tolstoy uses the metaphor in Anna Karenina $\left(1875^{-77}\right)$, in which the title character witnesses a death caused by falling under a train and subsequently commits suicide in the same way herself. William Alexander argues convincingly that Peck's fatal 
This hope in the power of accidents to encourage privileged people to work toward social cohesion with a wider populace is missing from the ending of A Hazard of New Fortunes. This novel's goal is similar to that of Annie Kilburn: it revolves around the possibility of uniting people diverse in region, gender, and political affiliation, this time through the literary magazine Every Other Week. In the opening episodes Fulkerson, Vance, and Basil March discuss how to please both New York readers and provincial readers. But different staff members interpret the aim of the magazine differently: publisher Conrad Dryfoos, the son of the magazine's nouveau-riche natural gas millionaire, hopes that the literary editor's sketches of New York City's neighborhoods might serve as a first step toward a world in which the comfortable people understand and care about how the uncomfortable people live; the literary editor Basil March vaguely imagines that the magazine will give young artists a chance; and the magazine's advertising head, Fulkerson, suggests soliciting firsthand material from a streetcar striker largely for the purposes of profit and prestige. In the course of the novel the fragile coalition of the magazine's staff becomes increasingly difficult to maintain and increasingly unlikely to bring about social harmony or activism.

The novel contrasts the methods of activist-theorists (the foreign submissions translator Berthold Lindau, Conrad Dryfoos, and Margaret Vance) with those of characters who vaguely desire to do good (Basil and Isabel March). ${ }^{32}$ Howells consistently uses the language of accidental entanglement in relation to the well-meaning bourgeois characters: Basil recognizes Lindau's socialist rhetoric because he has read similar rhetoric in labor newspapers he came across "accidentally" (Hazard, p. 194); during the strike demonstration, "Something stronger than [Basil's] will drew him to the spot" (p. 422). Such charac-

train accident is only one allusion to Tolstoy in a novel that contains an extended argument with Tolstoy's personal politics; he asserts that Howells had misgivings about the impracticality and ineffectiveness of living among the poor (see Howells: The Realist as Humanist, pp. 77-78).

${ }^{32}$ Like Boynton (and unlike Annie), the Marches are imperfectly detached observers: they do not come from an economic and social background privileged enough to shield them from economic downturns and working-class rebellion. Howells writes that Basil "began to feel like populace; but he struggled with himself and regained his character of philosophical observer" (Hazard, p. 374). 
ters exclaim hopefully that city space might contain a magic that would inspire social cohesion and action: Margaret Vance, for instance, speculates that "there seems to be some solvent in New York life that reduces all men to a common level, that touches everybody with its potent magic and brings to the surface the deeply underlying nobody" (p. 243; emphasis added). While the experiences of these characters prove their initial hopes wrong, the narrative itself uses similar devices of accident to knit people together. During their apartment hunt, Basil and Isabel March view a block of tenement houses "accidentally" (p. 64), because the driver of their hired coupé steers down that street without orders to do so. ${ }^{33}$ The magazine staff is bound together through accidental, chance meetings in public city space: Basil does not come to hire his long-lost teacher Berthold Lindau because he remembers the man's strengths, but because he runs into him in a restaurant; Conrad is inspired to intervene in the strike because Margaret Vance encounters him on the street. These incidents suggest that social connections across communities might happen spontaneously in the opportunity-filled streets of the city. (As fanciful as this wish may seem, similar feelings prompt twenty-first-century people to call for more urban public space.) In contrast, the narrative's conclusion in the horse-car strike and the dissolution of the magazine's staff dramatizes the idea that city accidents fail to create a common ground in which socially conflicted characters can come to consensus or understanding.

The horse-car strike is the narrative's most significant accident device. Kaplan argues that the strike is a return of the repressed that connects the narrative's middle-class, familial foreground to its background of the unreal city; by implicating its bourgeois characters in the immediate physical experience of the strike and the accompanying social disorder, Howells undercuts the tendencies of yellow journalism, documentary,

33 The incident constructs the Marches as mobile and the residents of the gay, crowded street as fixed in place: March remarks that the residents "are not merely carried through this street in a coupé, but have to spend their whole lives in it, winter and summer, with no hopes of driving out of it, except in a hearse" (p. 65). But given that the Marches themselves entered the street involuntarily, the incident does raise their awareness of the lives of the poor. 
and travel writing to cordon off urban life and working-class protest from middle-class reality. ${ }^{34}$ Unlike Mr. Peck's tragic death, the deaths of Conrad and Lindau do not inspire the less politically radical characters to put into action their ideas for change. Kaplan reads the strike violence as a wake-up call about the failure of the realist genre to foster social cohesion that works, and she reads Basil March's quandaries about God and economic chance as the impossibility of attaching meaning to terrible events. It is true that the novel's overall generic program and its accidents in particular fail to bring about social cohesion on a macro level, but it is possible to read in the narrative's ending the notion that accidental entanglement may motivate disparate characters to work together on a personal level: the strike, for example, gets the conversational ball rolling again among the surviving magazine staff. After the disastrous staff dinner and before the strike, none of the staff members were speaking to each other about Conrad's distaste for the job that made him valuable to them, the lack of seriousness about the legacy of slavery on the magazine's pages, or Dryfoos's miscomprehension of the situation between Christine Dryfoos and Angus Beaton. After the strike, however, the surviving members try to act on a newfound feeling that they are connected to each other and that they might very well try to make amends. The superficial Fulkerson is the one who tells Basil March that Lindau is dying. Dryfoos admits to Basil that he wishes he could explain his political convictions to Lindau and Conrad, even though the strike will eventually show him that his desire for discussion has come too late. Basil March is surprised at his own change in attitude, about "the willingness he had once felt to give this old man [Dryfoos] pain" (p. 449). When his wife wonders how it became possible for Dryfoos to change his attitude, Basil replies that only inner voices, not outer events, change

${ }_{34}$ See Kaplan, Social Construction, pp. 59-64, 15 $5^{1-55}$. Kaplan, along with other Howells critics, shows that in deference to his readership Howells was less radical in his writing than he was in his private thought. See also Daniel H. Borus, Writing Realism: Howells, James, and Norris in the Mass Market (Chapel Hill: Univ. of North Carolina Press, 1989), pp. 168-70; and Alexander, Howells: The Realist as Humanist. Thus, we cannot attribute the nonradical nature of the novel's ending to Howells's lack of personal conviction. 
people: "it is the still, small voice that the soul heeds; not the deafening blasts of doom" (p. 485). It is significant, of course, that Basil and Dryfoos meet again when Basil crosses Fifth Avenue in a daze, gets his hat bumped off his head by a horse, and is standing in the middle of the road blocking traffic when Dryfoos's coupé drives by. The accidents in the narrative provide a space for the characters to hesitate, rethink, and make decisions - they provide a space within modern life for heeding the "still, small voice."

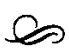

In Howells's version of realist accident, the devices of fatal injury and accidental entanglement create the perception that the destinies of all people are linked through involuntary and intangible connections. Fatal injuries serve to remind readers of the violence of the contemporary world and the social upheaval that would be necessary for social leveling to occur. Yet rather than suggesting in the novels that such violence is the inevitable, final word on modernity, Howells also includes accidental entanglement, which articulates the causal bonds created by modern travel and circulation that are easy to form but difficult to control. The characters that Howells identifies most strongly with a sense of accidental entanglement tend to be above the economic threshold of gentility and to have ample access to communication and transportation networks. He uses the accidents that these characters experience on trains or horse cars, or in reading, in order to expand their horizon of consciousness beyond their middle-class or elite circles. In both Annie Kilburn and A Hazard of New Fortunes Howells draws sharp contrasts between radical characters who act on the inequalities around them and bourgeois characters who accidentally stumble onto good works or radical views. Rather than focusing on the superiority of the heroic over the timid, he focuses on how difficult it would be to inspire privileged people to think beyond their densely self-interested perspectives.

In the course of these three novels Howells expresses less and less hope in the liberating potential of realist accident. In The Undiscovered Country only isolated characters critique 
the naturalness of human bonds created through accident, and the narrative ultimately upholds the social fiction of bonding through accident. In Annie Kilburn an accidentally entangled character is contrasted to an activist-theorist with a better sense of the changes that need to occur before Hatboro's conflicted residents feel a sense of togetherness, yet in the course of the novel Annie's sense of accidental entanglement eventually inspires her to help working-class reformers like the Savors put Mr. Peck's plan into action. In this way, the narrative offers a sense of hope for the efficacy of accidental entanglement. $A$ Hazard of New Fortunes offers less hope that the literary magazine and its well-meaning staff will decrease social fragmentation or social inequality, but it offers some hope on a micro level. This development suggests that Howells found less and less usability in realist accident in the course of his writing during this decade, one in which he became more resolutely socialist. Later Howells novels organized around random social connections, such as An Imperative Duty ( 1893 ) and The Landlord at Lion's Head (1897), do not mobilize the words and images of accident to nearly the same degree that the earlier novels do.

As Howells himself may have believed, his accident device possesses social and narrative limits: it stops short of fostering social transformation within the world of the novel, and hence, perhaps, it also stops short of fostering a radical social imagination among its readers. Once the radical characters of Annie Kilburn and A Hazard of New Fortunes die, the world they leave behind is focused on plausibility and personal security rather than change. Howells's realist accidents resist more challenging social alliances, such as alliances between Egeria Boynton and tramps, the literary magazine writers and striking workers, or Margaret Vance and the Dryfoos sisters. Kenneth W. Warren points out that realism was produced by and helped reinforce a postbellum politics in which African Americans were considered stuck in their current socioeconomic positions, and realist fiction avoided the melodramatic tropes of rescue and escape that had been central to Harriet Beecher Stowe's Uncle Tom's Cabin $\left(185^{2}\right)$ and other antislavery tracts. ${ }^{35}$ It is true that in his

${ }^{35}$ See Warren, Black and White Strangers, pp. 71-108. 
novels Howells steers clear of more politically radical visions of the legitimacy of equal opportunity for women, African Americans, or the Irish, yet his resolutely unradical nature has perhaps received too much attention in the history of Howells criticism. For late-twentieth-and early-twenty-first-century readers, however, Howells's realist accidents might read differently: as the impulse toward conversation and concern in a nonviolent modern world.

Bilkent University 